\title{
Effect of Various Doses of Kenikir Flower Crown Extract (Targetes erecta L.) on Reducing Blood Glucose Levels in Rats
}

\author{
Windi Yusika Kristanti*, M. Agus Krisno Budiyanto, Fendy Hardian Permana \\ Pendidikan Biologi, Fakultas Keguruan dan Ilmu Pendidikan, Universitas Muhammadiyah Malang. Jl. Raya \\ Tlogomas No. 246 Malang 65144, Indonesia. \\ *Corresponding author: windiyusika121@gmail.com
}

\section{ABSTRACT}

Diabetes mellitus is a metabolic disease caused by the body experiencing disturbances in controlling sugar levels, and the insulin hormone is impaired or does not meet the requirements. The purpose of this study was to analyze the effect of various concentrations of extracts of the crown of kenikir flower (Tagetes erecta L.) maceration method on decreasing blood glucose levels in white rats (Rattus norvegicus). The research approach used is a quantitative approach. Type of Research True Experimental Research, with the design of The Pre Test Post Test Control Group Design. Provision of kenikir flower crown extract (Tagetes erecta L.) using the maceration method with the help of n-hexane as solvent. This study used 5 treatment groups, namely a negative control group (alloxan), a positive control group (glibenclamide), an extract dose of $25 \mathrm{mg} / \mathrm{kgBW}$, an extract dose of $50 \mathrm{mg} / \mathrm{kgBW}$, and an extract $70 \mathrm{mg} / \mathrm{kgBW}$. Blood glucose levels were measured on day 1 (three days after induction) and day 24 (after treatment). The conclusion of this study was that a dose of $25 \mathrm{mg} / \mathrm{kgBW}$ gave the greatest decrease in blood glucose levels with a percentage value of $70 \%$ compared to the treatment group with a dose of kenikir flower crown extract.

Keywords: Blood glucose, Tagetes erecta L., Rat (Rattus norvegicus)

\section{ABSTRAK}

Diabetes melitus merupakan penyakit metabolik yang disebabkan karena tubuh mengalami gangguan dalam mengontrol kadar gula, serta hormon insulin mengalami gangguan atau tidak memenuhi syarat. Tujuan dari penelitian ini adalah untuk menganalisis pengaruh berbagai konsentrasi ekstrak mahkota bunga kenikir (Tagetes erecta L.) metode maserasi terhadap penurunan kadar glukosa darah pada tikus putih (Rattus norvegicus). Pendekatan penelitian yang digunakan adalah pendekatan kuantitatif. Jenis Penelitian True Experimental Research, dengan desain The Pretest Posttest Control Group Desain. Pemberian ekstrak mahkota bunga kenikir (Tagetes erecta L.) menggunakan metode maserasi dengan bantuan pelarut n-heksan. Penelitian ini menggunakan 5 kelompok perlakuan yaitu kelompok kontrol negatif (aloksan), kelompok kontrol positif (glibenklamid), ekstrak dosis $25 \mathrm{mg} / \mathrm{kgBB}$, ekstrak dosis 50 $\mathrm{mg} / \mathrm{kgBB}$, dan ekstrak $70 \mathrm{mg} / \mathrm{kgBB}$. Pengukuran kadar glukosa darah dilakukan pada hari ke-1 (tiga hari setelah diinduksi) dan hari ke-24 (setelah perlakuan). Kesimpulan dari penelitian ini adalah dosis 25 $\mathrm{mg} / \mathrm{kgBB}$ memberikan penurunan kadar glukosa darah yang paling besar dengan nilai persentase $70 \%$ dibandingkan dengan kelompok perlakuan pemberian dosis ekstrak mahkota bunga kenikir.

Kata Kunci : Glukosa darah, Tagetes erecta L., Tikus (Rattus norvegicus) 


\section{PENDAHULUAN}

Diabetes melitus merupakan penyakit metabolik yang disebabkan karena tubuh mengalami gangguan dalam mengontrol kadar gula, serta hormon insulin mengalami gangguan atau tidak memenuhi syarat. Pernyataan tersebut sesuai dengan pendapat Barky et al. (2017) penyakit diabetes mellitus (DM) adalah gangguan metabolisme kronis ditandai dengan kenaikan kadar glukosa darah serum. Menurut IDF (2019) International of Diabetes Federation secara global ada sekitar 463.0 juta orang dewasa terkena diabetes melitus dan diperkirakan akan terus meningkat pada tahun 2045 sekitar 700.2 juta orang dewasa berusia 2079 tahun, hidup dengan penyakit diabetes. Indonesia menempati peringkat ketujuh dari sepuluh negara dengan jumah penderita diabetes terbanyak di dunia. Diabetes mellitus merupakan penyakit yang tidak dapat disembuhkan, tetapi berpotensi untuk dapat dicegah dan dapat dikendalikan melalui pengobatan diabetes mellitus [1,2].

Pengobatan DM dengan menggunakan obat sintesis telah banyak dipergunakan seperti terapi insulin, meglitinide, sulfonylurea, dan golongan jenis obat sintetis lainnya [3]. Efek samping yang ditimbulkan dari penggunaan obat sintetis diantaranya yaitu, timbulnya rasa mual, hipoglikemia, pusing, tremor, muntah, konstipasi, resistansi, dan kerusakan organ lain (pengonsumsian obat oral yang berdampingan dengan diet) [4,5]. Adanya efek samping tersebut mendorong masyarakat mulai berpindah pada pengobatan herbal (tradisional) [6]. Pengobatan secara alami menggunakan obat herbal, dipilih karena biayanya murah, caranya yang relatif mudah serta tanaman obat herbal untuk diabetes mellitus dapat ditemukan di sekitar kita [4,7].

Tanaman yang dapat digunakan dalam obat herbal salah satunya adalah bunga kenikir (Tagetes erecta L.). Bunga Kenikir (Tagetes erecta L.) dapat dipergunakan sebagai penyembuhan berbagai penyakit $\left[{ }^{8}\right]$. Kenikir memiliki kandungan senyawa metabolisme sekunder, metabolisme sekunder merupakan molekul-molekul kecil yang bersifat spesifik, memiliki struktur yang beraneka ragam, setiap senyawa mempunyai fungsi yang berbeda-beda [9]. Bunga kenikir (Tagetes erecta L.) mengandung senyawa metabolisme sekunder berupa flavonoid dan saponin, pada serbuk bunga kenikir mengandung alkaloid, tanin, steroid atau triterpenoid, dan $80 \%$ adalah senyawa karotenoid jenis diester lutein $[8,10,11]$.

Berdasarkan penelitian sebelumnya oleh Purnamasari et al. (2013) hasil analisis karotenoid bubuk yang baik diekstrak menggunakan pelarut n-heksan dengan penggunaan suhu $140^{\circ} \mathrm{C}$. Pernyataan tersebut sesuai dengan Aristyanti et al. (2017) hasil rendemen dan hasil karakteristik dari ekstrak bunga (Tagetes erecta L.) pada pemberian jenis pelarut dan lamanya ekstraksi didapatkan perlakuan terbaik dalam hasil ekstrak pewarna bunga kenikir adalah pelarut n-heksan dan lama ekstraksi waktu 36 jam. Bagian bunga kenikir merupakan tanaman herbal yang bisa dimanfaatkan sebagai salah satu obat penyakit diabetes. Pernyataan tersebut sesuai dengan Kusmiati et al. (2019) bahwa senyawa lutein bunga marigold berpotensi sebagai antidiabetes dan antioksidan.

Sudah pernah diteliti mengenai daun kenikir (Cosmos caudatus) famili Asteraceae dengan efektivitas ekstrak etanol terhadap penurunan kadar glukosa darah pada tikus putih galur wistar dengan diinduksi aloksan, dimana ekstrak tersebut dapat menurunkan kadar glukosa darah [14]. Kebaruan dari penelitian ini adalah penggunaan bunga kenikir (Tagetes erecta $L$.) famili Asteraceae dengan bantuan pelarut $\mathrm{n}$ heksan terhadap penurunan kadar glukosa darah pada tikus putih galur wistar dengan diinduksi aloksan. Serta perbedaan penggunaan dosis ekstrak yang diaplikasikan pada tikus.

Tujuan dari penelitian ini adalah untuk menganalisis pengaruh berbagai konsentrasi ekstrak mahkota bunga kenikir (Tagetes erecta $L$.) dengan metode maserasi terhadap penurunan kadar glukosa darah pada tikus putih (Rattus norvegicus).

\section{METODE}

Penelitian True Experimental Research. Populasi yang digunakan dalam penelitian ini adalah tikus 
putih (Rattus norvegicus) yang hiperglikemia, umur 3 bulan, berasal dari laboratorium Farmakologi UMM, dan Sampel yang digunakan adalah 25 ekor tikus putih (Rattus norvegicus) yang hiperglikemia, kelamin jantan, berat badan 200 gram. Tempat Penelitian di Laboratorium Farmakologi dan Laboratorium Kimia UMM. Teknik pengumpulan data dengan bantuan alat glukometer. Pemeriksaan kadar glukosa darah tikus, dilakukan pada hari ke-1 (pretest) dan pada hari ke-24 (posttest) untuk melihat nilai penurunan kadar glukosa darah tikus. Teknis analisis data rata-rata selisih penurunan kadar glukosa darah tikus yang digunakan adalah hasil setelah diinduksi aloksan (pretest) dikurangi hasil setelah pemberian perlakuan (posttest). Data yang diperoleh diuji secara statistik menggunakan SPSS dan uji normalitas, homogenitas dilanjutkan dengan uji ANACOVA setelah itu dilanjutkan dengan uji post hoc. Uji normalitas data dengan menggunakan uji Shapiro-wilk dan didapatkan nilai yang signifikan $\mathrm{p}>0,05$ maka data berdistribusi secara normal. Uji homogenitas data menggunakan uji Levene's test, data yang terdistribusi normal menggunakan Uji ANACOVA dan dilanjutkan dengan uji Post Hoc dengan menggunakan Least Significant Difference (LSD) (apabila data normal dan homogen) atau uji Quade's rank analysis of covariance (apabila data tidak normal dan tidak homogen/non-parametrik).

\section{HASIL}

\section{Ekstraksi Bunga Kenikir}

Hasil rendemen ekstraksi mahkota bunga kenikir (Tagetes erecta L.) metode maserasi disajikan pada menyajikan tabel hasil rendemen ekstrak mahkota bunga kenikir sebanyak 500 g serbuk bunga kenikir dimaserasi menggunakan 2.500 liter n-heksana selama 36 jam dengan remaserasi $2 \mathrm{x}$, didapatkan hasil rendemen ekstrak kental sebanyak $7.042 \%$ (Lampiran 1). Penggunaan metode maserasi bertujuan untuk meminimalisir kemungkinan kerusakan senyawa bioaktif pada ekstrak dengan menggunakan suhu ruang [15]. Senyawa terbesar bioaktif yang dimiliki bunga kenikir adalah karotenoid jenis lutein ester yang termasuk golongan xantofil [16]. Penarikan senyawa bioaktif pada bunga kenikir menggunakan bantuan pelarut n-heksana. Penggunaan pelarut non-polar (n-heksana) dapat menghasilkan rendemen senyawa karotenoid yang tinggi dibandingkan pelarut semi-polar (aseton) pada proses ekstraksi [12].

\section{Hewan Percobaan}

Hewan yang digunakan dalam percobaan ini adalah tikus putih galur Wistar jantan (Rattus norvegicus). Hewan percobaan mengalami aklimatisasi terlebih dahulu selama 7 hari dengan tujuan untuk menyesuaikan kondisi lingkungan tikus yang baru [15]. Tikus yang sudah diaklimatisasi diinduksi diabetes melitus secara kimiawi dengan aloksan dosis 150 $\mathrm{mg} / \mathrm{kgBB}$ sebanyak 2 kali secara intraperitoneal, sehingga tikus mengalami kenaikan kadar glukosa darah terdapat tikus yang belum mengalami peningkatan kadar glukosa darah, maka tikus diinduksi lagi. Ada beberapa faktor tikus dapat mengalami kenaikan kadar glukosa darah bersifat sedang diantaranya, keadaan tikus yang stres setelah makan, dan kenaikan aktivitas tikus [17].

\section{Pengukuran Kadar Glukosa Darah Tikus}

Hasil penelitian berbagai dosis ekstrak mahkota bunga kenikir (Tagetes erecta L.) terhadap penurunan kadar glukosa darah tikus putih (Rattus norvegicus) dengan lima kali pengulangan selama 24 hari pengamatan disajikan pada Tabel 1 dan Tabel 2. 
Tabel 1. Hasil rerata kadar glukosa darah pada berbagai kelompok sebelum dan sesudah perakuan

\begin{tabular}{|c|c|c|c|}
\hline \multirow[t]{3}{*}{ Perlakuan } & \multirow[t]{3}{*}{ Ulangan } & \multicolumn{2}{|c|}{ Kadar Glukosa Darah (mg/dL) } \\
\hline & & Pre-test & Post-test \\
\hline & & (Hari ke-1) & (Hari ke-24) \\
\hline Kontrol (-) Aloksan 150 & K- (1) & 127 & 162 \\
\hline \multirow[t]{4}{*}{$\mathrm{mg} / \mathrm{kgBB}$} & $K-(2)$ & 135 & 199 \\
\hline & $\mathrm{K}-(3)$ & 140 & 189 \\
\hline & $\mathrm{K}-(4)$ & 135 & 189 \\
\hline & $\mathrm{K}-(5)$ & 140 & 200 \\
\hline Rerata \pm SD & & $135,40 \pm 5,320$ & $187,80 \pm 15,353$ \\
\hline Kontrol $(+)$ & $\mathrm{K}+(1)$ & 319 & 98 \\
\hline \multirow[t]{4}{*}{ Glibenklamid } & $\mathrm{K}+(2)$ & 398 & 91 \\
\hline & $\mathrm{K}+(3)$ & 441 & 105 \\
\hline & $\mathrm{K}+(4)$ & 371 & 112 \\
\hline & $\mathrm{K}+(5)$ & 391 & 87 \\
\hline Rerata \pm SD & & $384 \pm 44,407$ & $98,60 \pm 10,164$ \\
\hline Ekstrak mahkota bunga & K1 (1) & 273 & 93 \\
\hline \multirow[t]{4}{*}{ kenikir $25 \mathrm{mg} / \mathrm{kgbb}$} & K1 (2) & 199 & 88 \\
\hline & K1 (3) & 303 & 78 \\
\hline & K1 (4) & 306 & 73 \\
\hline & K1 (5) & 261 & 77 \\
\hline Rerata \pm SD & & $268,40 \pm 43,311$ & $81.8 \pm 8,349$ \\
\hline Ekstrak mahkota bunga & K2 (1) & 138 & 81 \\
\hline \multirow[t]{4}{*}{ kenikir 50 mg/kgbb } & $\mathrm{K} 2(2)$ & 151 & 91 \\
\hline & K2 (3) & 127 & 93 \\
\hline & K2 (4) & 151 & 91 \\
\hline & $\mathrm{K} 2(5)$ & 127 & 100 \\
\hline Rerata \pm SD & & $138,80 \pm 12,008$ & $91,20 \pm 6,797$ \\
\hline Ekstrak mahkota bunga & K3 (1) & 133 & 90 \\
\hline \multirow[t]{4}{*}{ kenikir 75 mg/kgbb } & K3 (2) & 148 & 92 \\
\hline & K3 (3) & 133 & 90 \\
\hline & K3 (4) & 127 & 92 \\
\hline & K3 (5) & 133 & 94 \\
\hline Rerata $\pm \mathrm{SD}$ & & $134,80 \pm 7,823$ & $91,60 \pm 1,673$ \\
\hline
\end{tabular}

Tabel 2. Hasil penurunan kadar glukosa darah pada berbagai kelompok

\begin{tabular}{ccc}
\hline Perlakuan & Ulangan & Kadar Glukosa Darah (mg/dL) \\
\cline { 3 - 3 } & & Pre-Post \\
\hline Kontrol (-) & K- (1) & -35 \\
Aloksan 150 & K- (2) & -64 \\
mg/kgBB & K- (3) & -49 \\
& K- (4) & -54 \\
Rerata \pm SD & K- (5) & -60 \\
Kontrol (+) & & $-52,40 \pm 11,283$ \\
Glibenklamid & K+ (1) & 221 \\
& K+ (2) & 307 \\
& K+ (3) & 336 \\
& K+ (4) & 259 \\
& K+ (5) & 304
\end{tabular}




$\begin{array}{ccc}\text { Rerata } \pm \text { SD } & & 285,40 \pm 45,324 \\ \text { Ekstrak mahkota } & \text { K1 (1) } & 180 \\ \text { bunga kenikir 25 } & \text { K1 (2) } & 111 \\ \text { mg/kgbb } & \text { K1 (3) } & 225 \\ & \text { K1 (4) } & 233 \\ \text { Rerata } \pm \text { SD } & \text { K1 (5) } & 184 \\ \text { Ekstrak mahkota } & \text { K2 (1) } & 186,60 \pm 48,459 \\ \text { bunga kenikir 50 } & \text { K2 (2) } & 57 \\ \text { mg/kgbb } & \text { K2 (3) } & 60 \\ & \text { K2 (4) } & 34 \\ \text { Rerata } \pm \text { SD } & \text { K2 (5) } & 60 \\ \text { Ekstrak mahkota } & \text { K3 (1) } & 27 \\ \text { bunga kenikir 75 } & \text { K3 (2) } & 47,60 \pm 15,852 \\ \text { mg/kgbb } & \text { K3 (3) } & 56 \\ & \text { K3 (4) } & 43 \\ \text { Rerata } \pm \text { SD } & \text { K3 (5) } & 35 \\ & & 39 \\ \end{array}$

Hasil Uji Normalitas (Shapiro-Wilk test)

Tabel 3. Hasil Uji Normalitas (Shapiro-Wilk test)

Tests of Normality

\begin{tabular}{lccccccc}
\hline & \multicolumn{2}{c}{ Kolmogorov-Smirnov $^{\mathbf{a}}$} & & \multicolumn{3}{c}{ Shapiro-Wilk } \\
\cline { 2 - 5 } \cline { 5 - 7 } & Statistic & df & Sig. & Statistic & df & Sig. \\
\hline Residual for Posttest & .124 & 25 & $.200^{*}$ & .924 & 25 & .064 \\
\hline
\end{tabular}

Berdasarkan hasil uji normalitas data pada Tabel 3 diketahui bahwa nilai data statistik Shapiro wilk test menginformasikan bahwa residual data penurunan kadar glukosa darah didapatkan nilai $[\mathrm{D}(25)=0,924$, sig. $=0,064$ ] sig. $>0,05$ data residual berdistribusi normal, maka asumsi normalitas terpenuhi.

\section{Hasil Uji Homogenitas (Levene's test)}

Hasil data yang telah di didapatkan berdistribusi normal, selanjutnya dilakukan uji homogenitas. Disajikan pada Tabel 4.

Tabel 4. Hasil Uji Homogenitas (Levene'S test)

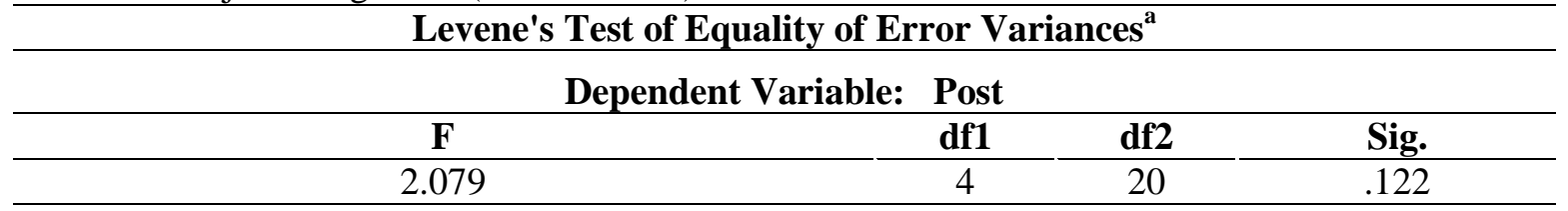

Tests the null hypothesis that the error variance of the dependent variable is equal across groups.

a. Design: Intercept + Pretest + KelompokTikus

Tabel 4 hasil uji homogenitas (Levene'S test) bahwa varians data penurunan kadar glukosa darah satu kelompok perlakuan dengan kelompok perlakuan yang lainnya dengan hasil $[\mathrm{F}(4,20)=2,079$, sig. $=$ 
0,122]. Sesuai dengan dasar pengambilan keputusan bahwa data sig. > 0,05 homogen sehingga, asumsi uji homogenitas dapat terpenuhi.

\section{Hasil Data Lenearitas}
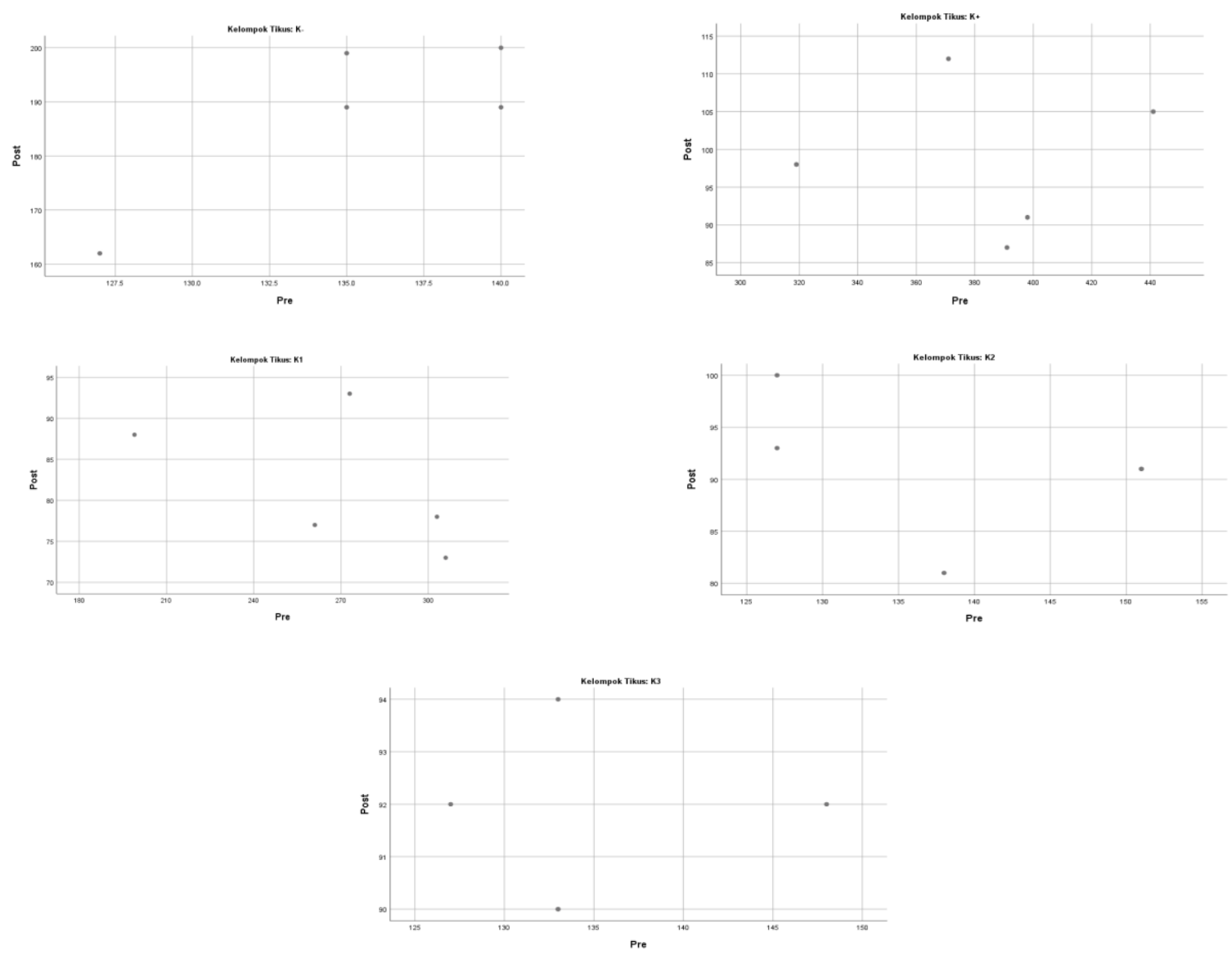

Gambar 1. Hasil keberadaan linearitas data kovarian dan data variabel terikat

Di setiap kelompok perakuan, data pretest linear terhadap data posttest penurunan kadar glukosa darah pada tikus. Dimaksudkan di setiap kelompok perlakuan data kovarian linearitas atau linear terhadap data variabel terikat.

Hasil Homogenitas Garis Regresi Ke-Lima Kelompok Perlakuan

Tabel 5. Tabel Hasil Homogenitas Garis Regresi ke Lima Kelompok Perlakuan

\section{Tests of Between-Subjects Effects}

Dependent Variable: Post

\begin{tabular}{cccccccc}
\hline Source & $\begin{array}{c}\text { Type III Sum of } \\
\text { Squares }\end{array}$ & df & $\begin{array}{c}\text { Mean } \\
\text { Square }\end{array}$ & F & Sig. & $\begin{array}{c}\text { Partial Eta } \\
\text { Squared }\end{array}$ \\
\hline Corrected Model & $39122.006^{\mathrm{a}}$ & 9 & 4346.890 & 61.629 & .000 & .974 \\
Intercept & 258.735 & 1 & 258.735 & 3.668 & .075 & .196 \\
KelompokTikus & 378.950 & 4 & 94.738 & 1.343 & .300 & .264 \\
Pretest & 300.442 & 1 & 300.442 & 4.260 & .057 & .221
\end{tabular}




$\begin{array}{ccccccc}\text { KelompokTikus * } & 750.133 & 4 & 187.533 & 2.659 & .074 & .415 \\ \text { Pretest } & 1057.994 & 15 & 70.533 & & \\ \text { Error } & 343781.000 & 25 & & & \\ \text { Total } & 40180.000 & 24 & & & \\ \text { Corrected Total } & & & & \end{array}$

a. R Squared $=.974$ (Adjusted R Squared $=.958$ )

Kemiringan regresi data pretest dengan data posttest penurunan kadar glukosa darah antara satu kelompok perlakuan dengan kelompok perlakuan yang lainnya bersifat homogen $[\mathrm{F}(4,15)=2,659$, sig. $=$ 0,074] nilai sig > 0,05 dapat disimpulkan asumsi homogenitas terpenuhi.

\section{Hasil Uji ANACOVA}

Tabel 6. rangkuman hasil uji hipotesis pada data ANACOVA

\begin{tabular}{|c|c|c|c|c|c|c|}
\hline \multicolumn{7}{|c|}{ Tests of Between-Subjects Effects } \\
\hline \multicolumn{7}{|c|}{ Dependent Variable: Post } \\
\hline Source & $\begin{array}{c}\text { Type III } \\
\text { Sum of } \\
\text { Squares }\end{array}$ & df & $\begin{array}{c}\text { Mean } \\
\text { Square }\end{array}$ & $\mathbf{F}$ & Sig. & $\begin{array}{c}\text { Partial Eta } \\
\text { Squared }\end{array}$ \\
\hline Corrected Model & $38371.872^{\mathrm{a}}$ & 5 & 7674.374 & 80.643 & .000 & .955 \\
\hline Intercept & 4981.866 & 1 & 4981.866 & 52.350 & .000 & .734 \\
\hline Pretest & 22.672 & 1 & 22.672 & .238 & .631 & .012 \\
\hline KelompokTikus & 33981.040 & 4 & 8495.260 & 89.269 & .000 & .949 \\
\hline Error & 1808.128 & 19 & 95.165 & & & \\
\hline Total & 343781.000 & 25 & & & & \\
\hline Corrected Total & 40180.000 & 24 & & & & \\
\hline
\end{tabular}

a. R Squared $=.955$ (Adjusted R Squared $=.943$ )

Hasil uji ANCOVA menunjukkan bahwa tidak terdapat perbedaan signifikan penurunan kadar glukosa darah antara satu kelompok perlakuan dengan kelompok perlakuan lainnya dengan mengontrol penurunan kadar glukosa awal kelompok perlakuan tikus $[\mathrm{F}(4,19)=89,269$, sig. $=0,000, \eta p 2=0,085]$ nilai sig. $<0,05$, maka kesimpulannya ada perbedaan signifikan, dengan mengontrol penurunan kadar glukosa awal tikus. Pengontrolan dibuktikan dengan variabel kovarian data pretes.

\section{Hasil Uji Lanjut Post Hoc (Least Significant Difference/LSD)}

Data hasil uji lanjut Post Hoc menggunakan uji $L S D$

Tabel 7. Hasil Uji Lanjut Post Hoc (LSD)

\begin{tabular}{lllllllll}
\hline $\begin{array}{l}\text { Kelompok } \\
\text { Perlakuan }\end{array}$ & M & (SD) & M & (SD) & Selisih & $\begin{array}{l}\text { Peningkat } \\
\text { an/Penuru }\end{array}$ & $\begin{array}{l}\text { Rerata } \\
\text { Terkorek } \\
\text { si }\end{array}$ & Notasi \\
\hline K1 & 268.4 & 43.311 & 81.8 & 8.349 & 186.6 & $70 \%$ & 83,891 & a \\
K2 & 138.8 & 12.008 & 91.2 & 6.797 & 47.6 & $34 \%$ & 88,462 & a \\
K3 & 134.8 & 7.823 & 91.6 & 1.673 & 43.2 & $32 \%$ & 88,713 & a \\
K+ & 384 & 44.407 & 98.6 & 10.164 & 285.4 & $74 \%$ & 104,999 & a \\
K- & 135.4 & 5.32 & 187.8 & 15.353 & -52.4 & $-39 \%$ & 184,953 & b \\
\hline
\end{tabular}


Hasil uji $L S D$ menyatakan bahwa kelompok perlakuan K1 tidak ada perbedaan yang signifikan antara kelompok perlakuan K2, kelompok perlakuan K2 tidak ada perbedaan yang signifikan antara kelompok perlakuan K3, kelompok perlakuan kotrol K3 tidak ada perbedaan yang signifikan antara kelompok perlakuan $\mathrm{K}+$, dan kelompok perlakuan $\mathrm{K}+$ ada perbedaan yang signifikan antara kelompok perlakuan K-.

\section{PEMBAHASAN}

\section{Hasil kadar glukosa darah pada berbagai kelompok sebelum dan sesudah perakuan}

Hasil data (Tabel 1) yang diperoleh dari pengukuran kadar glukosa darah pada berbagai kelompok perlakuan yang diberikan ekstrak mahkota bunga kenikir setelah tiga hari penginduksian didapatkan hasil rata-rata kadar glukosa darah pretest dengan nilai kelompok perakuan tertinggi adalah kelompok kontrol glibenklamid $(\mathrm{K}+)$ dengan nilai sebesar 384 $\mathrm{mg} / \mathrm{dL}$, diikuti dengan kelompok ekstrak dosis $25 \mathrm{mg} / \mathrm{kgBB}$ (K1) dengan nilai sebesar 268,40 $\mathrm{mg} / \mathrm{dL}$, setelah itu kelompok ekstrak dosis 50 $\mathrm{mg} / \mathrm{kgBB}$ (K2) dengan nilai sebesar 138,80 $\mathrm{mg} / \mathrm{dL}$, kelompok ekstrak dosis $75 \mathrm{mg} / \mathrm{kgBB}$ (K3) dengan nilai sebesar $134,80 \mathrm{mg} / \mathrm{dL}$, dan kelompok kontrol negatif (K-) dengan nilai $135,40 \mathrm{mg} / \mathrm{dL}$. Setelah 24 hari perlakuan hasil rata-rata penurunan kadar glukosa darah posttest diukur, didapatkan nilai tertinggi adalah, kelompok kontrol positif dengan nilai 98,60 $\mathrm{mg} / \mathrm{dL}$, diikuti dengan kelompok ekstrak dosis $75 \mathrm{mg} / \mathrm{kgBB}$ (K3) dengan nilai sebesar 91,60 $\mathrm{mg} / \mathrm{dL}$, setelah itu kelompok ekstrak dosis 50 $\mathrm{mg} / \mathrm{kgBB}$ (K2) dengan nilai sebesar 91,20 $\mathrm{mg} / \mathrm{dL}$, dan kelompok ekstrak dosis 25 $\mathrm{mg} / \mathrm{kgBB}(\mathrm{K} 1)$ dengan nilai sebesar $81,8 \mathrm{mg} / \mathrm{dL}$. Kelompok kontrol negatif (K-) terjadi peningkatan kadar glukosa darah dengan nilai sebesar $187,80 \mathrm{mg} / \mathrm{dL}$ peningkatan tersebut dikarenakan pemberian perlakuan aloksan. Menurut Maliangkay \& Rumondor (2018) aloksan merupakan zat yang diabetogenik dimana pada hewan uji dapat meningkatkan kadar glukosa darah melebihi batas normal. Dari hasil data tersebut didapatkan bahwa terjadi penurunan kadar glukosa pada kelompok perlakuan kecuali kelompok kontrol negatif.

Pengaruh Pemberian Berbagai Dosis Ekstrak Mahkota Bunga Kenikir (Tagetes erecta L.) Terhadap Penurunan Kadar Glukosa Darah Tikus Putih (Rattus norvegicus).

Hasil uji ANCOVA menunjukkan bahwa pemberian ekstrak mahkota bunga kenikir pada kelompok perakuan diabetes didapatkan nilai sig. < 0,05 $(0,000)$, pada kelompok tikus ada perbedaan signifikan, dengan mengontrol penurunan kadar glukosa awal tikus. Pengontrolan dibuktikan dengan variabel kovarian data pretes tiga hari setelah diinduksi aloksan. Hasil pengukuran kadar glukosa pada kelompok perlakuan yang diberikan ekstrak mahkota bunga kenikir menunjukkan bahwa terdapat pengaruh pemberian ekstrak mahkota bunga kenikir terhadap penurunan kadar glukosa darah pada tikus. Kusmiati et al. (2019) telah melaporkan bahwa ekstrak lutein pada bunga marigold berpotensi sebagai antidiabetes dan antioksidan pada tikus $S$. Dawley strain.

Tabel 7 menunjukkan bahwa nilai selisih penurunan kadar glukosa darah pretest dengan posttest didapatkan hasil tertinggi $\mathrm{K}+(285,4)$ perlakuan obat glibenklamid sebagai pembanding kelompok kontrol, menurut Sari et al. (2019) menyatakan bahwa obat glibenklamid sebagai obat pembanding bisa meningkatkan sekresi insulin. Diikuti dengan nilai terendah kelompok dosis ekstrak K1 $(186,6)$, kelompok dosis ekstrak K2 $(47,6)$, kelompok dosis ekstrak K3 $(43,2)$, dan diikuti dengan kelompok kontrol negatif $\mathrm{K}-(-52,4)$. Hasil persentase penurunan kadar glukosa darah pretest dan posttest dengan persentase tertinggi pada kelompok perlakuan $\mathrm{K}+$ dan $\mathrm{K} 1$, yaitu sebesar $74 \%$ dan $70 \%$, dibandingkan dengan nilai persentase terendah adalah kelompok, K2, K3, dan K- yaitu 34\%, $32 \%$, dan $-39 \%$. Kelompok K1 adalah perlakuan pemberian ekstrak dosis $25 \mathrm{mg} / \mathrm{kgBB}$ dengan nilai rerata tertinggi dari dosis pemberian ekstrak yang lain. Diduga karena adanya senyawa metabolisme sekunder yang terkandung di dalam ekstrak mahkota bunga kenikir (T.erecta L.) yang dapat menurunkan kadar glukosa darah pada tikus. Pernyataan tersebut sesuai dengan Handayani \& Mahanani (2019) menyatakan bahwa penurunan kadar glukosa 
darah tersebut diduga karena adanya senyawa metabolisme sekunder, senyawa kimia atau metabolisme sekunder dapat berpotensi sebagai hipoglikemik. Pendapat tersebut sesuai dengan yang dikemukakan oleh Maliangkay \& Rumondor (2018) penurunan kadar glukosa darah dosis $150 \mathrm{mg} / \mathrm{kgBB}$ lebih efektif dibandingkan dengan dosis $300 \mathrm{mg} / \mathrm{kgBB}$ disebabkan karena adanya senyawa yang terkandung di dalam kulit buah manggis yang memiliki efek antagonis terhadap sel sel penyusun pulau langerhans. Hal yang sama sesuai menurut pendapat Sukandar et al. (2011) efektivitas ekstrak etanol daun binahong pada ekstrak dimungkinkan mengandung senyawa yang antagonis dalam dosis lebih tinggi terjadi penurunan efek antidiabetes karena efek antagonisnya. Senyawa bioaktif yang dapat bersifat toksik apabila diberikan dalam jumlah dosis tinggi, dan dapat digunakan sebagai obat apabila diberikan dalam dosis rendah dalam uji toksisitas [21]. Hasil uji LSD didapatkan semua kelompok perlakuan dapat menurunkan kadar glukosa darah pada tikus, tidak ada perbedaan yang signifikan antara K1 dengan kelompok perlakuan yang lain yaitu, K2, K3, dan $\mathrm{K}+$. kelompok $\mathrm{K}+$ memberikan penurunan kadar glukosa darah dengan adanya perbedaan yang signifikan antara kelompok K-. Pemberian ekstrak mahkota bunga kenikir dengan pelarut $n$ heksan dosis $25 \mathrm{mg} / \mathrm{kgBB}$ memberikan penurunan kadar glukosa darah yang paling besar dengan nilai persentase $70 \%$ dibandingkan dengan kelompok dosis perlakuan yang lain dan tidak ada perbedaan yang signifikan antara kelompok perlakuan K- $(p<0,05)$. Perbedaan hasil penurunan kadar glukosa darah dimungkinkan karena Kandungan metabolisme sekunder yang diduga berperan dalam menurunkan kadar glukosa darah pada tikus antara lain karotenoid, flavonoid, saponin, tanin, dan steroid. Senyawa yang paling banyak dimiliki oleh bunga kenikir adalah lutein jenis karotenoid non provitamin A menjadi salah satu sumber utama pada saat ini [12,13,22]. Karotenoid dapat mengurangi stress oksidatif [23]. Flavonoid dapat menahan absorbsi karbohidrat sehingga kadar glukosa darah akan menurun [24]. Saponin dapat mencegah penyerapan glukosa menuju usus [14]. Tanin dapat menghambat glikolisis dan absorbsi glukosa [25]. Steroid dapat menstimulasi insulin yang keluar dari pankreas [26]. Simplisia mahkota bunga kenikir (Tagetes erecta L.) diekstraksi menggunakan metode maserasi. Tujuan dari adanya ekstraksi yaitu untuk menarik senyawa kimia yang terdapat pada bahan alam [27].

Hewan coba yang digunakan dalam penelitian ini adalah tikus galur wistar jantan (Rattus norvegicus) yang diinduksi dengan aloksan. Aloksan yang digunakan dalam penginduksian adalah dosis $150 \mathrm{mg} / \mathrm{kgBB}$ tikus, dimana dalam kondisi dosis tersebut tikus berhasil diinduksi meskipun dilakukan pemberian dosis berulang kali pada tikus yang belum hiperglikemik. Tikus yang hiperglikemia ditandai dengan kadar glukosa darah puasa > $126 \mathrm{mg} / \mathrm{kgBB}$ [14]. Tikus yang hiperglikemia disebabkan karena pemberian aloksan yang dapat menyebabkan kondisi hiperglikemia pada tikus, aloksan merupakan senyawa yang termasuk hidrofilik yang tidak stabil dan toksik selektif pada hati dan ginjal serta pemberian dosis yang tepat mengakibatkan destruktif selektif kepada sel beta pankreas. Diperoleh hasil kadar glukosa darah yang tidak sama meskipun pemberian dosis aloksan yang disamakan, hal tersebut dimungkinkan disebabkan karena faktor genetik dan kondisi internal hewan, tingkat stres dan aktivitas yang berbeda [17].

\section{KESIMPULAN}

Ekstrak mahkota bunga kenikir (Tagetes erecta L.) dengan dosis $25 \mathrm{mg} / \mathrm{kgBB}, 50 \mathrm{mg} / \mathrm{kgBB}$, dan $75 \mathrm{mg} / \mathrm{kgBB}$ dapat menurunkan kadar glukosa darah. Perlakuan dosis terbaik dalam penelitian ini adalah $\mathrm{K} 1$ dosis $25 \mathrm{mg} / \mathrm{kgBB}$

\section{DAFTAR PUSTAKA}

[1] Adnyana IDPA, Meles DK, Wurlina, Zakaria S, Suwasanti N. Efek Anti Diabetes Buah Pare (Momordica charantia Linn.) Terhadap Kadar Glukosa Darah, Sel Penyusun Pulau Langerhans dan Sel Leydig pada Tikus Putih Hiperglikemia. Acta Vet Indones. 2016;4(2):43-50. doi:10.29244/avi.4.2.43-50 
[2] Agustini NLPIB, Adiana IN, Dharmapatni NWK. Evaluasi pelaksanaan pilar utama diabetes pada pasien diabetes melitus tipe 2. J Ris Kesehat Nas. 2017;1(2):195-202. doi:10.37294/jrkn.v1i2.50

[3] Anwar K, Ngindra APL, Hariadi REP, Kamalia N, Santoso HB. Perbandingan efek ekstrak etanol, fraksi N- butanol, dan fraksi petroleum eter daun kembang bulan ( Tithonia diversifolia ( Hemsley ) A . Gray ) terhadap penurunan kadar glukosa darah mencit jantan yang diinduksi aloksan. Pharmascience. 2016;03(02):80-88. http://jps.unlam.ac.id

[4] Putra RJS, Achmad A, P HR. Kejadian efek samping potensial terapi obat anti diabetes pasien diabetes melitus berdasarkan algoritma naranjo potential side effects of anti-diabetic drug therapy in diabetes mellitus patients based on naranjo algorithm. Pharm $J$ Indones. 2017;2(2):45-50.

[5] Putri DKSC, Hermanto B, Wardani T. Pengaruh pemberian infusum daun salam (Eugenia polyantha) terhadap kadar glukosa darah tikus (Rattus norwegicus) yang diinduksi alloksan. Vet Med. 2014;7(1):7-16.

[6] Setyawati T, Lintin G. Efek ekstrak daun sirsak (Annona muricata) terhadap penurunan kadar trigliserida pada model tikus diabetes melitus. $J$ Kesehat Tadulako. 2016;2(2):1-72.

[7] Maliangkay HP, Rumondor R. Uji efektifitas antidiabetes ektrak etanol kulit buah manggis (Garcinia mangostana L ) pada tikus putih ( Rattus norvegicus ) yang diinduksi aloksan. Chem Prog. 2018;11(1):15-21.

doi:https://doi.org/10.35799/cp.11.1.2018. 27610

[8] Kusmiati, Caesarianto W, Afiati F, Hutabarat R. Effect lutein of marigold flower ( Tagetes erecta L.) on decreasing glucose and malondialdehyde levels in Alloxan-induced blood mice. In: AIP Conference Proceedings. Vol 2120. ; 2019:1-6.

doi:http://doi.org/10.1063/1.5115726

[9] Ergina, Nuryanti S, Pursitasari D. Uji kualitatif senyawa metabolit sekunder pada daun palado ( Agave angustifolia ) yang diekstraksi dengan pelarut air dan etanol. J Akad Kim. 2014;3(3):165-172.

[10] Wardani IGAK, Santoso P, Cahyaningsih E. Efektivitas sediaan granula bunga gumitir (Tagetes erecta L.) sebagai larvasida Aedes aegypti. Medicamento. 2015;4(2):130-134.

kusuma.wardhani21@ahoo.com

[11] Kusmiati, Wijaya IGAK, Yadi. Uji potensi antioksidan ekstrak lutein bunga kenikir ( Tagetes erecta ) berwarna kuning dan jingga dengan metode FRAP dan DPPH. Pros Sem Nas Masy Biodiv Indon. 2018;4(2):274-279.

doi:10.13057/psnmbi/m040231

[12] Purnamasari N, Andriani MA., Kawiji. Pengaruh jenis pelarut dan variasi suhu pengering spray dryer terhadap kadar karotenoid kapang oncom merah (Neurospora Sp.). J Teknosains Pangan Vol 2 No 2 April 2013. 2013;2(1):107114.

[13] Aristyanti NPP, Wartini NM, Gunam IBW. Rendemen dan karakteristik ekstrak pewarna bunga kenikir (Tagetes erecta L.) pada perlakuan jenis pelarut dan lama ekstraksi. J REKAYASA DAN Manaj AGROINDUSTRI. 2017;5(3):13-23.

[14] Pujiastuti E, Amilia D. Efektivitas ekstrak etanol daun kenikir (Cosmos caudatus Kunth) terhadap penurunan kadar glukosa darah pada tikus putih galur wistar ang diinduksi aloksan. Cendikia J Pharm. 2018;2(1):16-91.

http://cjp.jurnal.stikescendekiautamakudus .ac.id

[15] Prameswari OM, Widjanarko SB. Uji efek ekstrak air daun pandan wangi terhadap penurunan kadar glukosa darah dan histopatologi tikus diabetes mellitus. $J$ Pangan dan Agroindustri. 2014;2(2):1627.

[16] Sivel M, Kracmar S, Klejdus B. Lutein Content in Marigold Flower ( Tagetes erecta L .) Concentrates used for Production of Food Supplements. Czech J Food Sci. 2014;32(6):521-525.

[17] Saputra NT, Suartha IN, Dharmayudha AAGO. Agen Diabetagonik Streptozotocin untuk Membuat Tikus 
Putih Jantan Diabetes Mellitus. Bul Vet Udayana. 2018;10(2):116. doi:10.24843/bulvet.2018.v10.i02.p02

[18] Sari JDMS, Adam MR, Masruhim MA. UJI AKTIVITAS FRAKSI ETIL ASETAT BUAH GAMBAS (Luffa acutangula(L.) Roxb.) TERHADAP PENURUNAN KADAR GULA DARAH TIKUS PUTIH JANTAN (Rattus norvegicus). Pros Semin Nas. Published online 2019:169-175.

[19] Handayani SR, Mahanani PT. Uji Aktivitas Antidiabetes Infusa Daun Kemuning (Murraya Paniculata L Jack.) Pada Mencit Putih Jantan Yang Diinduksi Glukosa. UMS-Indonesia J Med Sci. 2019;6(1):3-7.

[20] Sukandar E, Qowiyyah A, Larasari L. Effect of Methanol Extract Hearhleaf Madeiravine (Anredera Cordifolia (Ten.) Steenis) Leaves on Blood Sugar in Diabetes Mellitus Model Mice. J Med Planta. 2011;1(4):245773.

[21] Wafa Aufia, Surya Amal NM. Uji toksisitas sub akut infusa daun afrika (Vernonina amygdalina Del.) terhadap histopatologi hati mencit (Mus musculus) galur BALB/c. Pharm J Islam Pharm. 2018;2(1):1-8.

[22] Ingkasupart P, Manochai B, Song WT, Hong JH. Antioxidant activities and lutein content of 11 marigold cultivars ( Tagetes spp .) grown in Thailand. Food Sci Technol. 2015;35(2):380-385.

[23] Delso NS, Rogers VA, Belzunces LP, et al. Systemic insecticides ( neonicotinoids and fipronil ): trends, uses, mode of action and metabolites. Env Sci Pollut Res. 2015;22(1):5-34. doi:10.1007/s11356-014-3470-y

[24] Kurniawaty E, Lestari EE. Uji efektivitas daun belimbing wuluh (Averrhoa bilimbi L.) sebagai pengobatan diabetes melitus. Majority. 2016;5(2):32-36.

[25] Fiana N, Oktaria D. Pengaruh kandungan saponin dalam daging buah mahkota dewa ( Phaleria macrocarpa ) terhadap penurunan kadar glukosa darah. Majority. 2016;5(4):128-132.

[26] Agustin L, Mulqie L, Choesrina R. Uji aktivitas antihiperglikemia ekstrak etanol daun sukun (ARTOCARPUS altilis (Parkinson Ex F.A.Zorn) Fosberg pada mencit Swiss Wester jantan dengan metode uji toleransi glukosa. In: Prosiding Penelitian SPeSIA Unisba 2015. ; 2015:324-331.

[27] Rupiniasih NN, Indriani, Syamsuddin, Razak AR. Aktivitas Antibakteri Fraksi N-Heksan, Kloroform, Etil Asetat Bunga Kamboja (Plumeria Alba) Terhadap Bakteri Staphylococcus Aureus Dan Salmonella Typhi. KOVALEN. 2019;5(2):173-181. 